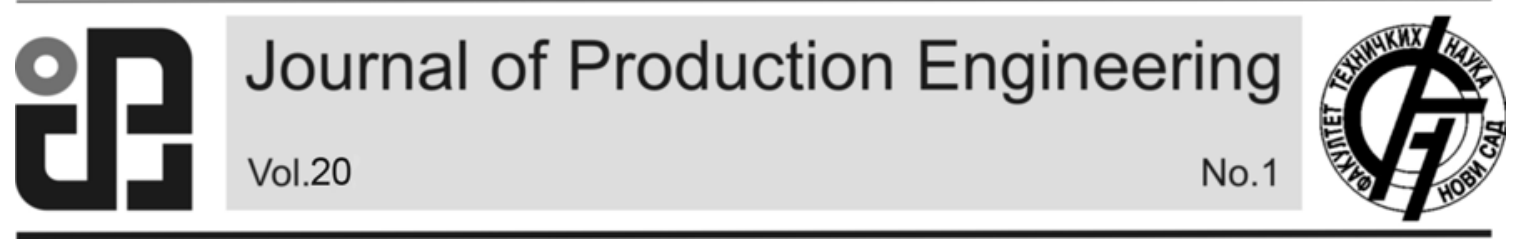

JPE (2017) Vol.20 (1)

Original Scientific Paper

Batinić, B., Rodić, D., Gostimirović, M., Kulundžić, N., Laković, N.

\title{
MONITORING OF THE DISCHARGE CURRENT BY HALL-EFFECT SENSOR
}

Received: 20 January 2017 / Accepted: 05 May 2017

\begin{abstract}
The paper describes the use of Hall-effect sensor to monitor the discharge current in electrical discharge machining (EDM). The discharge current across the gap between tool and workpiece is fed into developed acquisition system for the recording of impulses during processing. The data acquisition system consists of a sensor that works on the Hall element principle and microcontroller which collects and sends data on the PC that performs data acquisition. Experimental results have shown that discharge current and discharge duration can be clearly classified even with different machining conditions. The integration of the acquisition system can substantially improve the performance of the EDM process trought the analysis of discharge current.
\end{abstract}

Key words: discharge current, Hall-effect sensor, microcontroller, electrical discharge machining.

Praćenje procesa elektroerozivne obrade primenom Holovog senzora. Ovaj rad opisuje primenu Holovog senzora za praćenje struje pražnjenja tokom elektroerozivne obrade. Struja pražnjenja koja se pojavljuje između alata i obratka prolazi kroz akvizicioni sistem i vrši se njeno praćenje i snimanje tokom procesa obrade. Akvizicioni sistem se sastoji od senzora koji radi na principu Holovog efekta i mikrokontrolera koji prosleđuje signal za prikaz $i$ snimanje na računaru. Eksperimentalni rezultati pokazuju da struja pražnjenja i dužina trajanja impulsa mogu jasno klasifikovati pri različitim uslovima obrade. Integracijom sistema za akviziciju podataka omogućuje se analiza struje pražnjenja čime se postiže značajno poboljšati performance procesa elektroerozivne obrade.

Ključne reči: struja pražnjenja, Holov senzor, mikrokontroler, elektroerozivna obrada.

\section{INTRODUCTION}

Electrical discharge machining is one of the most widely applied process for machining and shaping hard, fragile and difficult-cutting alloyed tool steel in the tool industry [1]. Material is removed by means of repetitive spark discharges across the gap between the tool and workpiece [2]. Hence, the discharge current, discharge duration and pause time of the toolworkpiece gap form EDM pulses, which are often used to monitor the EDM process.

Generally, pulses of discharge current can be classified into several types, that is, open, spark, arc, off, and short pulses. Therefore, it is very important to develop a monitoring technique to classify various EDM pulses. Several well-known monitoring techniques including a transistor-controlled power supply [3], short-time-Fourier-transform [4], an emitted radio frequency analyserand a data dependent system modelling analyser $[5,6]$ have been reported in the EDM literature. These monitoring techniques use the preset and classifying various EDM pulses. A system for acquisition of current and voltage signals is presented in [7], which provides easy and reliable storage of the data acquired under various machining conditions. The system is based on a commercial dataacquisition board which performs data acquisition at

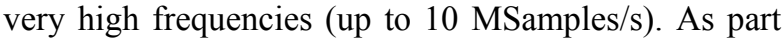
of a more complex system for detection of parameters that influence efficiency of the machining process, a virtual instrumentation system (VIS) is developed in [8], which measures relevant magnitudes, related to the occurrence of an increase in peak current, as well as increases and/or decreases in ignition delay time. The proposed real time acquisition system containes expensive NI6115 acquisition card, with 12-bit resolution analog channels and sampling rate of 5 Msamples/s. Systems for data acquisition described in the above mentioned papers represent effective solutions, however using expensive equipment.

In order to improve the machining efficiency, stability and quality the main objective of this paper is to create a low-cost monitoring system based on the Hall effect and microcontroller. The monitoring system is designed to monitor the performance of discharge current.

\section{PRINCIPLE OF DISCHARGE CURRENT MEASUREMENT}

Current impulses coming from the machining center are recorded using a sensor based on the Hall element. Hall element consists of a thin sheet of semiconducting material through which a current is passed. The output connections are perpendicular to the direction of current. When a perpendicular magnetic field is present, a potential difference (voltage) across the output is created and it is proportional to the applied magnetic field. This potential difference is very small, on the order of $\mu \mathrm{V}$, thus additional amplification is required in order to obtain desired voltage levels.

Fig.1 shows the current flow through the sheet. When no magnetic field is present, current distribution is uniform and no potential difference is seen across the output. When a perpendicular magnetic field is present, a Lorentz force is exerted on the current. This force 
disturbs the current distribution, resulting in a potential difference (voltage) across the output.

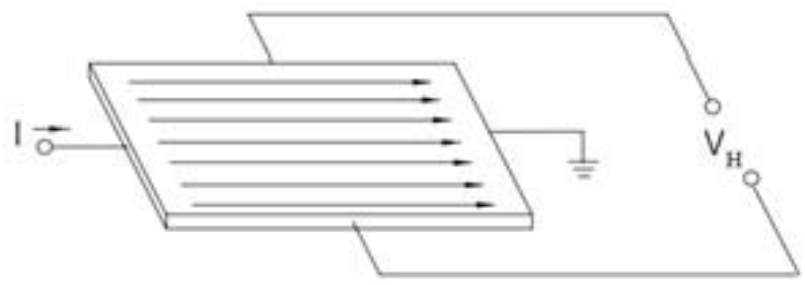

Fig. 1. Hall's element [9]

This voltage is the Hall voltage (VH). Hall element combined with an appropriate interface forms the sensor that utilizes Hall effect.

$$
\mathrm{V}_{\mathrm{H}}=\mathrm{I} \times \mathrm{B}
$$

Hall voltage is equal to the cross product of current intensity I and magnetic field B (1). This voltage is on the order of $\mu \mathrm{V}$. The necessary signal amplification is provided by the integrated on-chip differential amplifier [9]. The sensor used in this paper provides output voltage that is proportional to the applied magnetic field. The sensed magnetic field can be either positive or negative. As a result, the output of the amplifier will be driven either positive or negative, thus requiring both plus and minus power supplies. To avoid the requirement for two power supplies, a fixed offset or bias is introduced into the differential amplifier. The amplifier shown in Figure 2. must be a differential amplifier so as to amplify only the potential difference the Hall voltage.

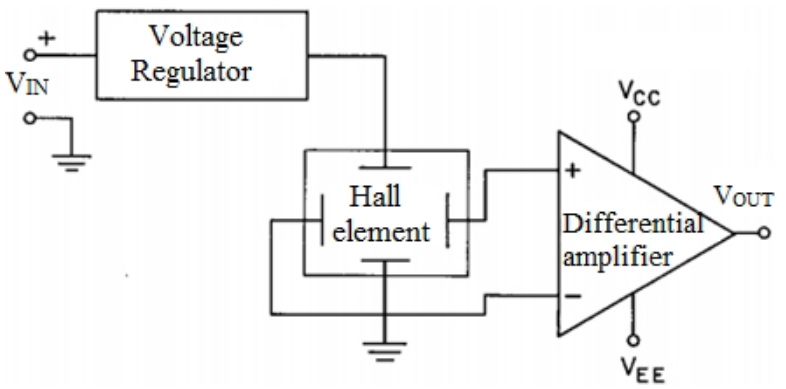

Fig. 2. Halls's sensor inside chipset [9]

This offset value appears on the output when no magnetic field is present and is referred to as a null voltage. When a positive magnetic field is sensed, the output increases above the null voltage as illustrated in Fig. 3.

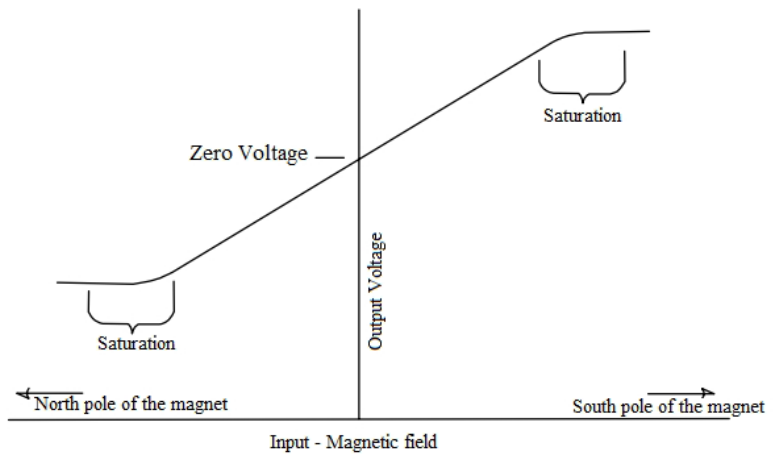

Fig. 3. Output signal of sensor vs. magnetic field [9]
The output of the amplifier cannot exceed the limits imposed by the power supply. The amplifier will begin to saturate before the limits of the power supply are reached. Hence, the saturation takes place in the amplifier, not in the Hall element. Therefore, large magnetic fields will not damage the Hall effect sensor, but rather drive it into saturation.

\section{ACQUISITION SYSTEM}

Hardware of the measuring device consists of a current measuring module based on the Hall effect ACS712 and a microcontroller dsPIC30F4012 whose role is to process the measured data and provide communication with PC. ACS712 sensor is selected because of its operating range (up to $30 \mathrm{~A}$ ), and the microcontroller dsPIC30F4012 was chosen because its integrated $\mathrm{A} / \mathrm{D}$ converter has sufficient resolution to process impulses coming from the EDM device. It is important to point out that the electronic module that performs acquisition is galvanically isolated from the EDM device, hence there is no danger from occurrence of highcurrent or high-voltage impulses.

The current measuring module is connected in series with the electrode. Analog signal from the sensor module ACS712 is converted using an integrated A/D converter. Then this information is buffered within certain timeframe and then forwarded to the PC using serial RS232 communication, where it is further processed and stored using appropriate software. A/D converter is based on the successive approximation architecture (SAR) and allows maximum sample rate of 1 Msps (using 10-bit resolution). In order to further increase the sample rate, reference voltages are provided to the converter, which limit the expected voltage from zero voltage to the saturation voltage of the sensor. The machining center with the connected measuring system consists: microcontroller, current measuring sensor, interface for communication with PC and software for data acquisition.

\subsection{Algorithm of microcontroller firmware}

Microcontroller code is written in the $\mathrm{C}$ programming language, and the corresponding algorithm is shown in Fig. 4. In the initialization phase, the clock frequency is set and the RS232 serial communication and A/D converter are initialized. The speed of RS232 serial communication is set to 525 kbps. A/D converter generates interrupt routine after each conversion and stores the data in the buffer.

Programme is executed in an infinite loop, where it is checked if the buffer with the data from $\mathrm{A} / \mathrm{D}$ conversion is ready, and if the condition is met the buffered data is sent to PC using serial communication after which the buffer is reset. Programme then resumes execution in the loop.

\subsection{PC software}

The microcontroller forwards the data to the PC with processing software developed on the LabVIEW platform. The application consists of the front panel presented in Fig. 5 and the block diagram, which controls the operation of the application in the 
background by receiving data from the serial port and calculating the intensity of current impulses based on the data from the $\mathrm{A} / \mathrm{D}$ converter. This calculation is not performed directly on the microcontroller in order to save time for additional conversions.

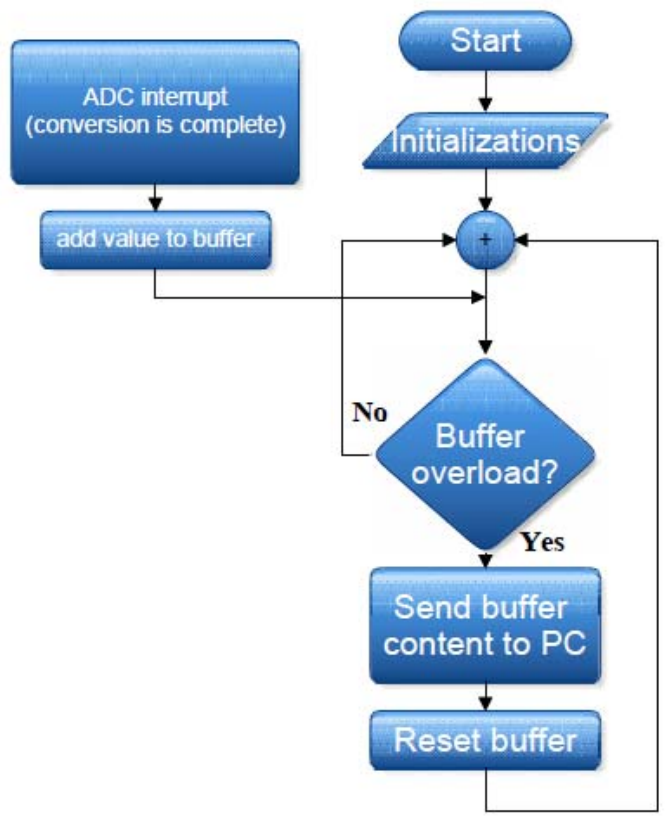

Fig. 4. Firmware Algorithm of Microcontroller

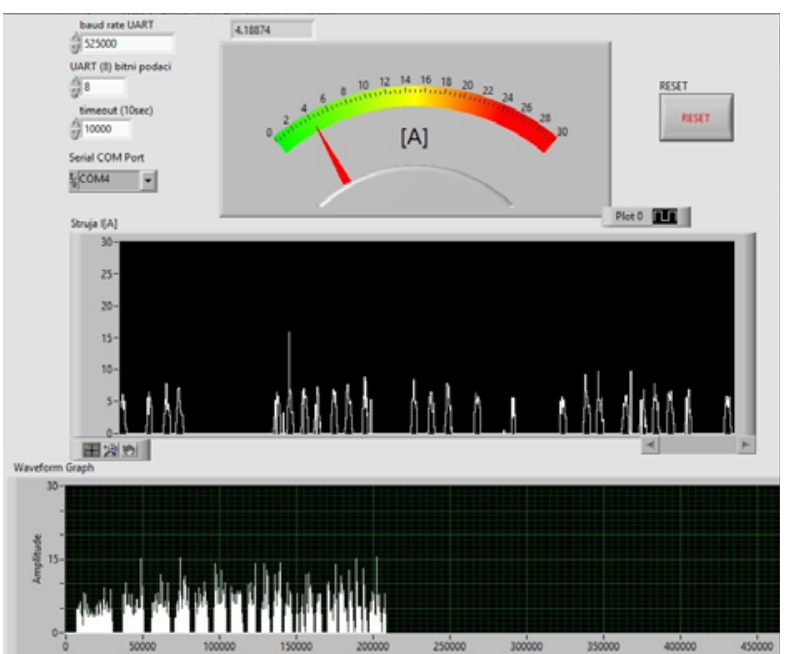

Fig. 5. Interface for communication with PC

Data about current impulses is presented on the display using analog scale and graphically using current view and continual view. After the processing is done, the data is exported in an excel fire for further analysis.

\section{RESULT AND DISCUSSION}

The experiments were performed on a CNC EDM SP1U machine. Rectangular graphite was used for an electrode to erode a workpiece of ductile iron DI 400. The discharge current between the tool and workpiece was directly measured from the EDM machine.

The most important electrical pulse parameters of EDM are discharge current and pulse duration [10]. These parameters directly influence the machining performance, and that is why their monitoring is important.

Experimental results have shown that the developed system can correctly for recording various EDM pulses. Several examples are shown in the following.

The peak current is the maximum intensity of the current passing through the electrodes for a given pulse. The average peak discharge current is the mean of the peak discharge current values measured in a period of time. It is known that the discharge energy is influenced by the discharge voltage, discharge current, and pulse duration. The discharge current directly impacts the discharge energy [11]. If the discharge current oversteps the limit for the given machining conditions like on figure 8 , the stability of the impulse discharge will be threatened. This process initiates continuous current flow and occurrence of arcing or short circuiting. This lengthens the time required to deionize the discharge channel, thus reducing the efficiency of EDM. In the other words, the deionization of the discharge zone would be affected, resulting in either low or uncontrolled output machining caracteristcs. The pulse duration is another parameter which allows direct control of discharge energy. However, here too the independent regulation of process parameters is limited. It is known from experience that pulse duration must be limited for a particular discharge current. Otherwise, electric arcing occurs, damaging both the tool and workpiece.

Figure 6 shows the discharge current $6 \mathrm{~A}$ and discharge duration $12 \mu \mathrm{s}$. The average discharge current pulse duration can be used to distinguish between different types of discharges. It was evaluated for all the current pulses as the distance between current pulse end time and current pulse start time identified as shown in Fig. 7. Figure 7 also show an example of discharge stability. Unstable machining is show on figure 8 .

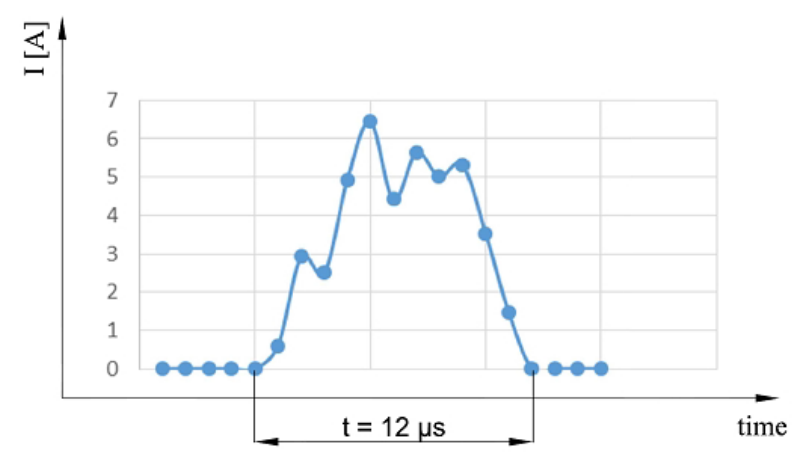

Fig. 6. Impulse measured during EDM machining

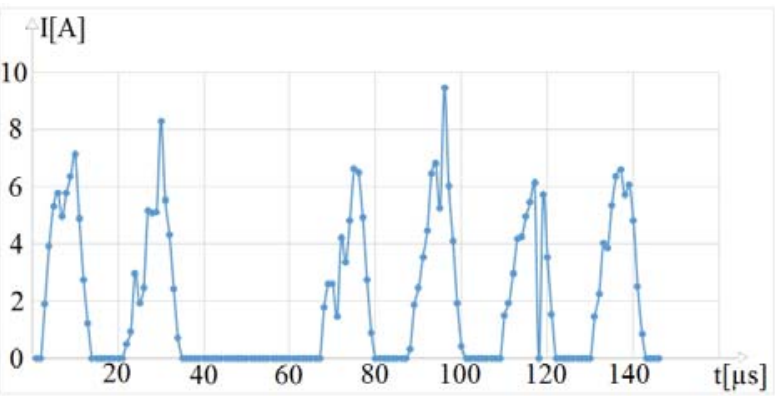

Fig. 7. An example of discharge stability 


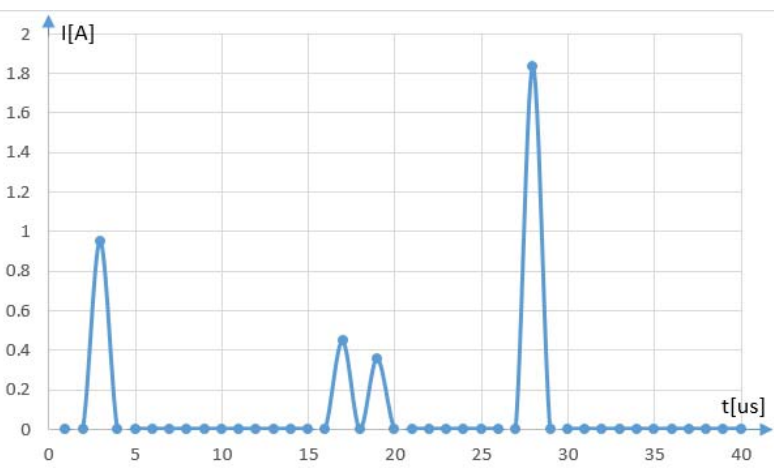

Fig. 8. An example of discharge unstability

\section{CONCLUSION}

In this paper a low-cost system for acquisition of current impulses measured on the basis of Hall sensor is presented. The acquisition system is paired with a machining center. The machining center does not provide functionality of detailed acquisition of current impulses, hence not offering detailed insight in the machining process. The proposed acquisition system has proven to provide a reliable way of monitoring the result of the machining process at a low-cost by means of data acquisition. The obtained data enables us to observe if the result of the machining process is in accordance with the parameters provided by the manufacturer. Furthermore, the data is stored for future analysis. A potential improvement of this methodology is the realization of a pulse classification algorithm based on artificial intelligence.

\section{REFERENCES}

[1] J. Schey, Introduction to Manufacturing Processes3rd, New York: McGraw-Hill, 2000.

[2] H. Liu, Y. Tarng, Monitoring of the electrical discharge machining process by abductive networks, The International Journal of Advanced Manufacturing Technology, 13 (1997) 264-270.

[3] M.-T. Yan, H.-T. Chien, Monitoring and control of the micro wire-EDM process, International Journal of Machine Tools and Manufacture, 47 (2007) 148-157.

[4] S. Yu, B. Lee, W. Lin, Waveform monitoring of electric discharge machining by wavelet transform, The International Journal of Advanced Manufacturing Technology, 17 (2001) 339-343.

[5] D. Dauw, R. Snoeys, W. Dekeyser, Advanced pulse discriminating system for EDM process analysis and control, CIRP Annals-Manufacturing Technology, 32 (1983) 541-549.

[6] S. Pandit, T. Mueller, Verification of on-line computer control of EDM by data dependent systems, J. Eng. Ind., 109 (1987) 117-121.

[7] E. Portillo, I. Cabanes, M. Marcos, D. Orive, J.A. Sánchez, Design of a Virtual-Instrumentation System for a Machining Process, IEEE Transactions on Instrumentation and Measurement, 56 (2007) 2616-2622.
[8] I. Cabanes, E. Portillo, M. Marcos, J. Sánchez, Online prevention of wire breakage in wire electrodischarge machining, Robotics and ComputerIntegrated Manufacturing, 24 (2008) 287-298.

[9] Honeywell, "MICRO SWITCH Sensing and Control”, Freeport, Illinois 61032, 005715-2-EN IL50 GLO.

[10] H. Kansal, S. Singh, P. Kumar, Performance parameters optimization (multi-characteristics) of powder mixed electric discharge machining (PMEDM) through Taguchi's method and utility concept, (2006).

[11] M. Gostimirovic, P. Kovac, M. Sekulic, B. Skoric, Influence of discharge energy on machining characteristics in EDM, Journal of Mechanical Science and Technology, 26 (2012) 173-179.

\section{ACKNOWLEDGMENT}

This paper is the result of the research within the project TR 35015 financed by the Ministry of Science and Technological Development of the Republic of Serbia.

Authors: Research Associate Branislav Batinic MSc, Research Associate Dragan Rodć MSc, Professor Marin Gostimirović PhD, Research Associate Nenad Kulundžić MSc, Nikola Laković MSc.

University of Novi Sad, Faculty of Technical Sciences, Trg Dositeja Obradovica 6, 21000 Novi Sad, Serbia, Phone.: +381 21 450-366, Fax: +381 21 454-495.

E-mail: banebb@uns.ac.rs, rodicdr@uns.ac.rs maring@uns.ac.rs kulundzic@uns.ac.rs, lakovicn@uns.ac.rs. 